Karolina Starego

ORCID: 0000-0001-9232-7067

Uniwersytet Gdański

karolina.starego@ug.edu.pl

\title{
Troska o świat i zadanie jego wspólnej przebudowy, czyli o Korczakowskiej uwspólniającej utopii w działaniu
}

\section{Summary}

To take care of the world and to build it together. Korczak's "utopia in action" as a practice of commonality

The aim of this paper is to reconstruct Korczak's notion of "utopia in action". The notion is based on the philosophy of education concerned with creating of what is common. In this analysis I leave aside Korczak's "paidocentrism" and focus on the communal elements in his thought - such as the care for the world that is also a call for its shared reconstruction, and the ontological force of love for the world and the people that populate it. Such an interpretation of Korczak's thought allows it to become a topical alternative for the essentialist, antagonistic and exclusive ideas concerning community education

Keywords: Janusz Korczak, love for the world, pedagogy of commonality, communal education

Słowa kluczowe: Janusz Korczak, miłość do świata, pedagogika wspólnotowości, edukacja wspólnotowa

Czerpanie teoretycznych i praktycznych inspiracji z pedagogicznej klasyki wiąże się zwykle z odpowiedzią na uprzednio, explicite bądź implicite, zadane pytanie o jej aktualność. Jednocześnie za miarę aktualności danej koncepcji edukacyjnej należy uznać nie tylko to, czy odpowiada ona na współcześnie stawiane pytania, ale również to, czy sama pozwala stawiać pytania, o których, bez jej udziału, trudno by było nawet pomyśleć. Idee pedagogiczne Janusza Korczaka, których fragment stanowi przedmiot prowadzonych w artykule rozważań, należą do grupy koncepcji edukacyjnych stawiających w centrum zainteresowania warunki możliwości zaistnienia i realizacji zasad równości, solidarności, braterstwa/siostrzeństwa i współpracy, a więc fundamentów rzeczywiście wspólnego nie tyle wspólnie zarządzanego, ile raczej kooperatywnie wytwarzanego oraz „gospodarzonego" - świata. Tym samym w świetle aktualnej uporczywej dominacji tendencji separatystycznych oraz karykaturalnych sposobów im przeciwdziałania pozwala ona na nowo zdefiniować warunki konstytuowania się solidarnych, równościowych i nieesencjalistycznie pojmowanych zbiorowości. 
Jak podkreślają badacze, mimo stopniowej utraty przez edukację formalną szczególnej roli formacyjnej (Biesta 2006; Masschelein, Simmons 2008) nadal pozostaje ona istotnym kontekstem utrwalania nawyków w zróżnicowanych sposobach organizacji zbiorowości (Lewis 2008; Starego 2017; Kowzan 2018), z których tylko marginalna część może odpowiadać na współczesne zapotrzebowania, wyznaczane deficytowością alternatywnych form praktykowania współpracy (Kowzan 2017, 2018). Innymi słowy, szkoła wdraża, ale niekoniecznie właściwie i do właściwych - z perspektywy ich etycznych, społecznych i politycznych konsekwencji - form i sposobów zawiązywania się wspólnot. W takim kontekście teoretyczne inspiracje w refleksji nad teorią i praktyką wspólnotowego życia i działania nabierają szczególnego znaczenia. Pozwalają bowiem formować niezbędną dla edukacyjnej praktyki społeczną/polityczną wyobraźnię.

Artykuł jest próbą (re)interpretacji najbardziej fundamentalnych założeń edukacyjnej filozofii Korczaka w kontekście opartej na idei wspólnie konstruowanego świata koncepcji wspólnotowości. Odczytanie Korczaka w tej perspektywie nie oznacza kolejnego - w świetle bardzo bogatej literatury „okołokorczakowskiej” - zestawienia poglądów Korczaka na temat dziecka, jego obywatelskości czy przynależnych, a nadal nieuwzględnianych praw. Jest raczej próbą spojrzenia na - skądinąd dobrze znane szerszemu odbiorcy - elementy Korczakowskiej filozofii edukacji przez pryzmat zróżnicowanych filozoficznych i pedagogicznych koncepcji, które pozwalają naświetlić istotę Korczakowskiego spojrzenia na problem wspólnie (re)konstruowanego świata.

W tym celu w pierwszej kolejności opisano - jak się wydaje, fundamentalny, choć często pomijany - kontekst Korczakowskiej teorii i praktyki wychowawczej, jakim jest troska o świat, której istotę stanowi miłość do będących jego częścią ludzi (nie tylko dzieci). Dzięki odniesieniu do filozofii Hannah Arend oraz jej filozoficznych i pedagogicznych reinterpretacji autorstwa różnych filozofów edukacji (m.in. Jorisa Vlieghe, Piotra Zamojskiego) oraz do koncepcji teoretycznie i praktycznie zbliżonej do Korczakowskiej, jaką jest teoria Paula Freirego, pokazany zostaje ontologiczny, a nie tylko ontyczny charakter miłości do świata i ludzi jako istoty głębokiej troski o jego stan. W efekcie teoria Korczaka zostaje rozwinięta w perspektywie koncepcji opisującej możliwości konstytuowania się tego, co wspólne, na zasadach równego i symetrycznego udziału wszystkich zaangażowanych, jaką jest egalitarna teoria „trzeciego terminu” (Starego 2016a). Wszystko to z kolei składa się na fundamenty - implicite tutaj rekonstruowanej - Korczakowskiej „uwspólniającej" utopii w działaniu, wiążącej się z szerszym, bo społecznie zaangażowanym wymiarem edukacyjnej filozofii Korczaka.

Celowo zatem, zamiast na pajdocentryzm, uwaga kierowana jest na kolektywistyczne i „wspólnototwórcze” elementy refleksji Korczakowskiej, co oznacza podążanie tropem kwestionowanej obecnie za ideologiczność i koniunkturalizm interpretacji Lewinowskiej (Smolińska-Theiss 2013), kładącej nacisk na szersze, a więc społeczne i kulturowe, konteksty edukacyjnej filozofii Korczaka. W swoim Tryptyku pedagogicznym Aleksander Lewin pisze mianowicie, że wbrew utartym mniemaniom ,punktem wyjścia działalności i twórczości Korczaka było nie tyle dziecko, ile raczej świat, w którym to dziecko żyje 
i na który jest skazane" (Lewin 1986: 32). Podobnie do Lewina w eseju na temat Korczaka Zygmunt Bauman zauważa, że mimo dominującej wykładni kluczem do jego „myśli i czynów" jest nie tyle samo dziecko i bezgraniczna miłość do niego, ile człowieczeństwo, którego żywy obraz ono stanowi (Bauman 2002).

Co więcej, opisywana przez wielu autorów i autorek jako sedno Korczakowskich idei miłość do dziecka odzwierciedla w myśli Korczakowskiej w istocie więcej niż się na pozór wydaje. Wykracza bowiem poza samo dziecko i dotyka poziomu ontologicznego. Jako określona postawa wobec świata (Hodgson, Vlieghe, Zamojski 2018) jest miłością do tego, co w ujęciu Korczaka w świecie najcenniejsze i co tym samym stanowi właściwy punkt wyjścia refleksji oraz działań edukacyjnych: „Korczak walczył o godność dziecka nie tylko w imię radosnego dzieciństwa, ale także dla dobra dorosłych, na jakich dzieci wyrosną. To właśnie dlatego, że taki cel miał na widoku, uznał Korczak za najlepszy środek traktowanie dziecka w sposób, w jaki dorośli winni być, ale w naszym świecie rzadko bywają, traktowani” (Bauman 2002).

W takim ujęciu pomijane jako marginalne z punktu widzenia personalistycznych i aksjologicznych ujęć myśli Korczakowskiej problemy społeczne, takie jak niesprawiedliwość oraz wykluczenie (Smolińska-Theiss 2013), stają się istotnym punktem wyjścia (re)interpretowanej tutaj filozofii edukacji. Jej oś wyznacza ontologiczna troska o świat, pociągająca za sobą imperatyw, by nie zostawiać go takim, jakim jest (cyt. za: Lewin 1986: 33).

\section{Ontologiczna troska o świat}

W kontrowersyjnym w świetle współczesnych standardów myślenia o edukacji eseju pod tytułem Kryzys edukacji Hannah Arendt pisze o ochronie tego, co rewolucyjne i nowe, jako jednym z podstawowych zadań edukacji: „Aby chronić świat przez śmiertelnością jego twórców i mieszkańców, należy go ciągle odnawiać. Problem polega po prostu na tym, by wychowywać w taki sposób, aby odnawianie to było wciąż możliwe, nawet jeśli nigdy nie uda się tego w pełni urzeczywistnić. Nasza nadzieja spoczywa zawsze w nowym, które przynosi ze sobą każde pokolenie; ale właśnie dlatego, że tylko na tym możemy opierać nasze nadzieje, niweczymy wszystko, kiedy my, starzy, próbujemy roztaczać nad tym, co nowe, kontrolę dyktującą, jak ono ma wyglądać" (Arendt 2011: 23).

Wskazując wpisany w aktywność wychowawczą paradoks intencji i celów oraz efektów wychowania, Arendt pisze o od wieków obecnym w tradycji myśli pedagogicznej mechanizmie, czyniącym z nowego pokolenia zakładnika przyszłej, planowanej poza jego kontrolą i intencjonalnym udziałem zmiany. Jej zdaniem domeną europejskich ruchów politycznych była edukacja połączona $\mathrm{z}$ charakterystycznym dla nich przekonaniem, że stworzenie nowego porządku powinno się zaczynać od tego, co rzeczywiście w świecie nowe, a więc dzieci (Arendt 2011: 214-215). Aby jednak dzieci spełniły pokładaną w nich nadzieję, muszą zostać poddane pieczołowitej opiece wychowawczej, dzięki czemu edukacyjny projekt społeczny i tożsamościowy nie wymknie się spod kon- 
troli. Podstawą tegoż - jak twierdzi Arendt - zawsze były zapędy dyktatorskie, czyli „,ingerencja oparta na absolutnej wyższości dorosłego i próba wytworzenia nowego jako faktu dokonanego" (Arendt 2011: 214). W efekcie nawet tak szczodre w zamyśle cele, jak kształtowanie przyszłych obywateli przyszłego państwa/społeczeństwa, zawsze są w istocie odmową politycznego i społecznego udziału: „Każde nowe pokolenie wzrasta w starym świecie, w związku z czym przygotowanie nowego pokolenia dla nowego świata może znaczyć jedynie to, że chce się wytrącić z rąk przybyszy ich własną szansę na to, co nowe" (Arendt 2011: 215).

To niezwykle charakterystyczne, nie tylko dla utopii społecznych, ale i liberalnie pojętych projektów transformacji tożsamościowej i społecznej (Starego 2016a), zjawisko, o którym pisze Arendt, przybiera również inną formę, będącą rewersem skierowanej w przyszłość logiki formatorskiej. Jest nią „odmowa teraźniejszości”, której istotę stanowi legitymizowana odmowa udziału w szeroko pojętej rzeczywistości „tu i teraz” olbrzymim rzeszom ludzi: od dzieci przez różne kategorie społeczne dorosłych (Starego 2016a). Jest ona tym samym formą znaturalizowanej nie tylko w praktyce społecznej czy edukacyjnej, ale i w naukach społecznych czy humanistycznych (socjologii, pedagogice, a nawet filozofii) (Rancière 2004) przemocy, której transparentność wynika między innymi z przywoływanego przez nią kryterium: wieku, rozwoju, kompetencji oraz wykształcenia (Rancière 1991; Biesta 2013b).

Korczak, podobnie do Arendt, doskonale zdawał sobie sprawę, że kontrola nad rzeczywistością, a więc nad tym, co tu i teraz, w dużej mierze sprawowana jest dzięki kontroli nad przyszłością. Jego koncentracja na teraźniejszości (Korczak 1984) oraz waloryzacja codzienności (Kubicka 2016) stanowią zatem jednoznaczne odrzucenie - zidentyfikowanej przez niego jako przemocowa, bo opartej na postulatywnej retoryce (Szkudlarek 2018) - logiki zmiany rozwojowej od „być powinno” do ,jest” (Starego 2016a). Gdzie to pierwsze (,być powinno") stanowi podstawę normatywnej oceny i zakwestionowania tego, co istnieje (,jest") w imię jedynego, pozytywnie waloryzowanego stanu idealnego (Starego 2016a; Szkudlarek 2018).

Mimo że Korczaka nie interesowało to, jakie dziecko być powinno, ale jakie jest tu i teraz, a wszelkie próby określania oddalonego w czasie stanu docelowego wychowania jednoznacznie identyfikował w kategoriach przemocy, aktualny stan oraz tendencje rozwojowe obserwowanej przez niego rzeczywistości nie były mu obojętne. Co więcej, właściwa Korczakowi „apokaliptyczna wizja świata: dekadenckiego, źle zorganizowanego, poddanego działaniu irracjonalnych impulsów, samounicestwiającego się, zmierzającego nieuchronnie ku zagładzie. [...] rządzonego przez homo rapax i homo vurgalis" (Lewin 1986: 33) w zasadniczy sposób warunkowała jego wyobrażenia o sposobach radykalnego przeobrażenia nie tylko szerszych stosunków społecznych, ale i ludzi jako jednostek moralnych (Lewin 1999). Jeśli więc - jak pisał Korczak - „tragedią jest życie współczesne i hańbą jest dla tego pokolenia, które przekazuje świat nieuporządkowany" (cyt. za: Lewin 1986: 33), gruntowna przebudowa oznaczała dla niego w pierwszym rzędzie zmianę stosunków społecznych świat ten definiujących. 
Ponieważ zobowiązanie wobec świata oznaczało jednoczesne zobowiązanie wobec najsłabszej, wykluczonej, najbardziej pokrzywdzonej części ludzkości, która w perspektywie możliwej zmiany stawała się wręcz gwarantującą nowy porządek „,klasą rewolucyjną", Korczak - podobnie jak inni praktycy i teoretycy emancypacyjnych koncepcji pedagogicznych - zdawał sobie sprawę, że najbardziej fundamentalna zmiana musiała się wiązać z radykalnym zakwestionowaniem i w dalszej kolejności - odrzuceniem zastanych sposobów dystrybucji i legitymizacji władzy, a zatem udostępnieniem nie tylko świata, ale także przede wszystkim umożliwieniem aktywnego udziału w jego tworzeniu jednostkom $\mathrm{z}$ tego procesu do tej pory wykluczonym (Lewin 1999). Podobnie jak Paulo Freire, Korczak widział możliwość odbudowy świata przez zerwanie z dehumanizacją i przemocą. Świat, z którego kreacji aktywnie wyłączona jest część ludzkości, nigdy nie może być w pełni ludzki (Freire 2007).

Pesymistyczna konkluzja wynikająca z obserwacji i analizy aktualnych Korczakowi zjawisk społeczno-politycznych nie stała się jednak podstawą rozwinięcia typowej emancypacyjnej czy krytycznej koncepcji edukacji, gdzie zagadnienie zmiany rozpatrywane jest w kategoriach oddalonych w czasie efektów procesów podmiotowych/tożsamościowych i społecznych. Powodowana uzasadnioną - szczególnie w tamtym okresie - katastroficzną obawą i jednocześnie głęboką troską o świat jako miejsce życia ludzi chęć jego odnowy i odbudowy nie była zatem tym rodzajem utopii, która z powodów strukturalnych lub jednostkowych musiałaby poczekać na swoją realizację w odległej przyszłości. I z tych samych przyczyn być może nigdy nie dojdzie do skutku (Rancière 1991).

Jednocześnie jego podejście do możliwej zmiany nie przyjmowało formy zadeklarowanego konserwatyzmu Arendt, która w imię troski o świat i prawa dzieci do nowości postulowała de facto ich izolację - powołując się, poza typowo filozoficznym uzasadnieniem, na psychologizujące (Biesta 2013a) kryterium kompetencyjne i rozwojowe (Arendt 2011). Jej zdaniem „konserwatyzm, w sensie zachowawczości, należy do istoty działalności edukacyjnej, której zadaniem zawsze jest pielęgnowanie i ochrona czegoś - dziecka przed światem, świata przed dzieckiem, nowego przed starym i starego przed nowym" (Arendt 2011: 231). Co prawda, jak zwraca uwagę Zygmunt Bauman, chęć ochrony człowieczeństwa, które uosabiało dla Korczaka dziecko (o czym już była mowa we wstępie), stała u podstaw prób dosłownej ochrony dzieci przed światem, które w skrajnej formie i tuż przed najtragiczniejszymi wydarzeniami miały się realizować zamykaniem drzwi sierocińca na klucz czy zamurowywaniem jego dolnych okien (Bauman 2002). Z kolei postulowana przez Arendt „ochrona świata przed dzieckiem”, której odzwierciedleniem jest jej zdecydowany sprzeciw wobec jakichkolwiek prób włączenia dzieci w bieżące sprawy społeczno-polityczne (Arendt 2011), stało w całkowitej sprzeczności z Korczakowskim pedagogicznym credo.

Wprowadzanie zmian, będących odzwierciedleniem Korczakowskiej troski o świat, realizowało się wedle odmiennej logiki. Jej charakter wydaje się doskonale obrazować przywołana przez irlandzką filozof edukacji Sharon Todd ilustracja zaczerpnięta z powieści amerykańskiego pisarza Cormaca McCarthy’ego (Todd 2010). W swojej książce 
Droga przedstawia on świat po bliżej nieokreślonej katastrofie, gdzie pozostali przy życiu ludzie prowadzą zredukowaną do walki o przetrwanie egzystencję. Bohaterami powieści są podróżujący drogą ojciec z synem. Ich podróż nie ma celu poza przemieszczaniem się od jednego schronienia do drugiego. Świat po apokalipsie jest - jak podkreśla Todd przepełnionym przemocą Hobbesowskim koszmarem. Poza spotkaniem ze schorowanymi, rannymi i szalonymi nieznajomymi bohaterowie natykają się na grupy ludzi, dla których przeżycie w postapokaliptycznym świecie oznacza walkę na śmierć. I właśnie w tym świecie bez nadziei, bez przyszłości, bez świętości figura dziecka - a przede wszystkim to, co ono uosabia - jest zdaniem Todd kluczem do zrozumienia istoty edukacji poza opisanym wcześniej pedagogiczno-psychologicznym teleologicznym determinizmem. Przedstawiona w książce postać dziecka istnieje całkowicie poza przeszłością i przyszłością, nie prezentuje się ani jako efekt katastroficznych bieżących warunków i okoliczności, ani jako realizowany wychowawczo i nastawiony na przyszłość czy przyszłą zakładaną tożsamość projekt ojca. Istnieje wyłącznie w perspektywie bieżącego tu i teraz, kształtowanego przez codzienne spotkania z innymi, które ujawniają jego transgresję od okoliczności dotkniętych wszechobecną przemocą, egoizmem i brakiem odpowiedzialności. Wbrew racjonalnemu ojcu i konformizmowi czy doprowadzonemu do skrajności egoizmowi innych przyjmuje odpowiedzialność, potwierdzając ją jednocześnie w każdym geście podczas kontaktu ze spotkanymi ludźmi.

Zdaniem Todd przedstawione w powieści dziecko jest czystym wydarzeniem rozbijającym współczesną mu egoistyczną racjonalność innych i pozbawioną człowieczeństwa postapokaliptyczną rzeczywistość. Nie ma przyczyn ani celu, ale jest całkowicie określane przez definiujące je tu i teraz, które może się uaktualnić tylko w kontakcie z innymi ludźmi. Jest zatem tym, co jako pozytywny element świata przetrwało w figurze dziecka, którego tożsamość jest konstruowana wyłącznie w samym procesie spotkania. W taki też sposób, a więc przez swoje niezdeterminowane uobecnienie, staje się moralną i polityczną obietnicą dla świata i jego nowego otwarcia. Świat w takim ujęciu ma możliwość odnowy, bo odnawiany jest nowością, którą wnosi do aktualnych warunków dziecko, wchodzące $\mathrm{w}$ interakcję z innymi i niezdeterminowane żadnym teleologicznym projektem, jako nosiciel/-ka człowieczeństwa.

Przywołana przez Todd ilustracja procesu edukacyjnej transformacji jako uobecniania się pozwalającego na pojawienie się czegoś nowego, wydaje się również doskonałą metaforyczną egzemplifikacją Korczakowskiej idei odnowy czy rekonstrukcji świata, gdzie kluczową rolę odgrywa dziecko reprezentujące to, co w świecie najlepsze. Figura dziecka uosabiająca człowieczeństwo - jak pisał przywoływany na wstępie Bauman - staje się automatycznym punktem wyjścia całego procesu. Dzieje się tak nie z racji przyświecających projektowi celów podmiotowych i społecznych (jak w opisywanej wcześniej postulatywnej logice transformacji) ani przez jej izolację od tego, co publiczne (jak w wypadku konserwatyzmu Arendt), ale właśnie wbrew tym celom oraz dzięki temu, że nie kto inny, ale właśnie dziecko ma możliwość wzięcia odpowiedzialności - samodzielnie, bez niczyjej edukacyjnej ingerencji oraz bez wizji idealnej przyszłości, wyznaczającej dokładną 
tożsamościową i społeczną drogę dojścia - tu i teraz wobec świata oraz innych, którzy są jego częścią. „Tak, jestem jedynym - odpowiadało dziecko” (cyt. za: Todd 2010: 2) w powieści Droga na zniecierpliwione upomnienia ojca, że nie jest jedynym, który powinien się o wszystko martwić.

Przytoczony opis nie ma być oczywiście ilustracją Korczakowskiego pajdocentryzmu, ale wskazaniem na ontologiczne warunki możliwości procesu rekonstrukcji rzeczywistości. W jednym ze swoich artykułów Tomasz Szkudlarek pisze o strukturalnie oraz egzystencjalnie doświadczanym i po punkowsku rozumianym „braku przyszłości” (No Future!) jako ontologicznym warunku edukacji skoncentrowanej na aktualnych możliwościach trudnych do pomyślenia i realizacji w innych warunkach. Edukacji, która - jak podkreśla Szkudlarek - pojawia się poza temporalnymi i teleologicznymi ramami orientacyjnymi, na zgliszczach przewidywalnych struktur odniesienia, łechtających ego hierarchii, norm czy tożsamości, i która tym samym może stanowić nowe otwarcie dzięki redefinicji dotychczasowych sposobów organizowania rzeczywistości (Szkudlarek 2017: 51).

W takiej nie tylko teoretycznej, ale także odnoszącej się do aktualnego doświadczenia rzeczywistości (Szkudlarek 2017) perspektywie zilustrowany przez Todd i po Arendtowsku rozumiany proces uobecniania się jako stawania się tego, co nowe, jest $\mathrm{w}$ istocie odzwierciedleniem szerszego ontologicznego procesu odnawiania rzeczywistości, o który wydawał się zabiegać w swoich pedagogicznych ideach Korczak. W czasach rzeczywistego kataklizmu, naruszającego wcześniejsze wyobrażenia najbliższej i dalszej przyszłości, widział on edukację jako sposób na zawieszenie dotychczasowych mechanizmów dystrybucji władzy, kompromitację przyszłościowo zorientowanych projektów tożsamościowych oraz afirmatywne zderzenie $\mathrm{z}$ tym, co nieprzewidywalne i trudne do kontroli. Edukację oznaczającą, że odarty z dotychczasowych punktów odniesienia świat zostaje otwarty do wspólnej rekonstrukcji, również dla tych, którzy do tej pory z tego procesu byli wykluczani.

\section{Miłość, „trzeci termin” i wspólna rekonstrukcja świata jako filary Korczakowskiej utopii w działaniu}

Można zatem - jak się wydaje - bez wahania powiedzieć, że dla Korczaka - nieco inaczej niż dla Arendt, w której wypadku ontologicznym uwarunkowaniem człowieka jest po Heideggerowsku rozumiane „,wrzucenie w świat, który nie jest naszym dziełem” (Vlieghe 2016: 28) - ontologicznym wymiarem ludzkiego bytowania jest po Freirowsku/Marksowsku rozumiana transformacja świata jako realizacja człowieczeństwa. Jednocześnie, w pewnej analogii do Arendt, proces odnawiania rzeczywistości jest możliwy dzięki określonej postawie wobec świata (Hodgson, Vlieghe, Zamojski 2018), odzwierciedlającej twórczą ontologiczną siłę, która leży w samym sercu Korczakowskich idei - jest nią miłość do świata.

Należy jednak zaznaczyć, że w wypadku Arendt miłość do świata jest miłością do tego, co istnieje, co jest warte zachowania i co w efekcie jest bardziej istotne niż miłość do 
ludzi, a przede wszystkim do dzieci. Wspominany wcześniej konserwatywny wymiar edukacji, polegający na ochronie świata przed dziećmi, oznacza u Arendt, że muszą one być poddane ekspozycji na świat, który już istnieje i który z racji tego zawsze jest już naszym wspólnym światem (Arendt 2011; Vlieghe 2016). W przeciwieństwie do tych poglądów zarówno u Freirego, jak i Korczaka miłość do świata jest jednoczesną i nieoddzielną miłością do ludzi, którzy są jego częścią i którzy stanowią żywe uosobienie tego, co w nim najważniejsze i co powoduje, że świat ten ciągle na nowo, wspólnymi siłami może być nieustannie wytwarzany jako wspólny. Tym natomiast, co powoduje przybierającą wiele postaci jego destruktywną degenerację, jest wykluczenie części ludzkości z brania udziału w tym procesie i w efekcie przywłaszczanie sobie świata przez pozostałą część. Miłość jest zatem siłą, która pozwala wszystkim uczestnikom skierować się do świata, a dokładnie rzecz ujmując - na wspólnie realizowane zadanie wytwarzania świata jako wspólnego.

Podejmowana w takiej perspektywie teoria edukacyjna Korczaka stanowi kolejny przykład pedagogiki, którą można określić jako pedagogikę zapośredniczenia i mediacji (Starego 2016a), a której istotą jest obecność „trzeciego terminu” (Starego 2016a) w edukacyjnej relacji. Joris Vlieghe, odwołując się do „klasycznego trójkąta dydaktycznego”, rozumianego jako zespolenie nauczyciela, ucznia i rzeczy, nazywa podobne podejście „pedagogiką skoncentrowaną na rzeczy” (Vlieghe 2016: 28). W obu wypadkach chodzi o istnienie elementu pośredniczącego między dziećmi/uczniami/uczennicami a dorosłymi, który eliminuje immanentne w tej relacji dominację, władzę oraz przemoc i czyni je symetrycznymi, a tym samym bardziej równymi (Starego 2016a). Jest to zarazem wyjście poza ,jednocentryczną" koncepcję edukacyjną, a więc „,dorosłocentryczną" koncentrację na nauczycielu i ,pajdocentryczną" koncentrację na uczniu (Vlieghe 2016: 28), której przekonującą krytykę, zbieżną z podejściem Korczaka, przedstawia Arendt. Jej zdaniem szczególnie w drugim wypadku mamy do czynienia z dzieleniem świata - tak jakby istniały dwa niezależne od siebie rzeczywistości - i w efekcie nieredukowalnym oddzielaniem od siebie dwóch generacji (Arendt 2011; Vlieghe 2016). Podobnie dla Korczaka jednym z głównych społecznych i pedagogicznych problemów było działanie zakładające istnienie blisko siebie i obok siebie dwóch światów, których mieszkańcy nie żyją razem, ale osobno - każdy dla siebie (Korczak 1978a, b). Zdaniem Vlieghe edukacyjną możliwością przezwyciężenia tegoż, odzwierciedlającą jednocześnie głęboką miłość do świata i pozwalającą na jego odnowienie oraz w efekcie - na czynienie go naszym wspólnym, jest ,umieszczenie” między dwiema generacjami rzeczy rozumianej jako edukacyjnie eksponowane aspekty świata, podlegające wspólnej uwadze, poświęceniu, trosce i namysłowi (Vlieghe 2016). Podobnie u Korczaka - tym, co leży między dorosłymi a dziećmi i jednocześnie łączy ich we wspólnym zadaniu (Korczak 1978b) odnowy, jest sam świat, $\mathrm{z}$ tą jednak różnicą, że odnowa oznacza tutaj proces wspólnego wytwarzania go na nowo.

W tym wypadku zatem Korczakowi bliżej do podzielającego podobne idee Freirego, u którego konflikt między uczniami i nauczycielami (a szerzej między opresjonowanymi i opresorami) przezwyciężana jest przez ich wspólne zwrócenie się do mediującego ich relację obiektu, a więc wspólnie rekonstruowanego w całym procesie świata (Stare- 
go 2016a). W takim ujęciu świat jest nie tylko „dawkowany” - eksponowany młodemu pokoleniu w specjalnych edukacyjnych warunkach, by był przedstawiony taki, jaki jest (Arendt 2011), a w dalszej kolejności - odnowiony, ale zostaje oddany w swoim niezapośredniczonym wymiarze do aktywnej wspólnej rekonstrukcji, by taki właśnie nie pozostał tu i teraz.

Podobnie jak w przywołanym wcześniej literackim ujęciu warunków nowego początku, nie tylko świat jest wyeksponowany w swojej nagiej brutalności przed dzieckiem, ale również dziecko wystawione na świat ma możliwość podjęcia odpowiedzialności za jego wytwarzanie na nowo. Jeśli miłość do świata oznacza jego zachowanie przez odnowę, miłość do ludzi i świata wymaga jego odnowy przez wspólnie przez nich realizowaną konstrukcję tego, co wspólne.

O ile w „konserwatywnym” podejściu Arendt krytyka włączania dzieci w aktualne problemy społeczno-polityczne wynika, po pierwsze, z ontologicznego założenia o istnieniu wspólnego świata, który należy, niejako dla siebie, dopiero uczynić wspólnym, po drugie - z przyjmowanej przez nią „,rozwojowej” koncepcji dzieciństwa (Biesta 2013a) jako $\mathrm{z}$ definicji stanu nierówności (Arendt 2011), po trzecie - z definiowania sfery publicznej jako zarezerwowanej dla równych sobie uczestników (w której dzieci zawsze będą poddanymi), i wreszcie last but not least - z idei miłości do świata, który istnieje niejako poza ludźmi, o tyle w charakterystycznej dla Korczaka (i Freirego) „witalistycznej” antropologii i ontologii dzieje się we wszystkich tych wypadkach coś dokładnie odwrotnego, co jednocześnie nie zalicza się do przekonująco przedstawionych (przywoływanych wcześniej) przez Arendt problemów.

Zamiast dziecka jako człowieka in statu nascendi mamy dziecko-człowieka, zamiast gotowego świata dla wszystkich mamy świat do stworzenia przez wszystkich dla wszystkich - siłą miłości nie tylko do świata, ale i do ludzi, którzy są jego konstytutywną częścią. Tak więc Korczakowski utopijny model współżycia społecznego dzieci i dorosłych, oparty na wspólnym uczestnictwie w przebudowie świata oraz życia na zasadach sprawiedliwości, braterstwa, równych praw i obowiązków (Lewin 1999), nie wymagał - jak pokazała Korczakowska praktyka - spełnienia żadnych dodatkowych warunków poza koniecznością wprowadzania go w życie tu i teraz (Korczak 1928).

Jak podkreśla Lewin, Korczak jako ideowe dziecko swojej epoki podzielał najbardziej humanistyczne idee ówczesnych twórców, takich jak Edward Abramowski czy Stanisław Brzozowski, dla których wartości, takie jak równość, sprawiedliwość, solidarność i przede wszystkim braterstwo, stanowiły jedyne możliwe fundamenty dla kreacji nowego wspólnego świata (Lewin 1999). Nie była to zatem oddalona w czasie utopijna idea idealnego świata, który jest możliwy do osiągnięcia przez uprzednie wychowanie do niego ludzi, ale utopia w działaniu, której realizacja polega na - raczej rozumianym po Rancièrowsku pozytywnym aksjomacie działania, umożliwiającym kooperatywne przekształcanie rzeczywistości tu i teraz. 


\section{Literatura}

Arendt H. (2011), Kryzys edukacji. W: H. Arendt, Między czasem minionym a przyszłym. Warszawa, Wydawnictwo Aletheia.

Bauman Z. (2002), Dzieciństwo godności ludzkiej. „Midrasz”, 12. http://midrasz.pl/archiwum. php\#article-content, 12.06.2019.

Biesta G.J.J. (2006), Beyond Learning. Democratic Education for a Human Future. Boulder, London, Paradigm Publishers.

Biesta G.J.J. (2013a), The Beautiful Risk of Education. Boulder, London, Paradigm Publishers.

Biesta G.J.J. (2013b), Time Out: Can Education do and be Done Without Time? W: T. Szkudlarek (ed.), Education and the Political. Rotterdam, Boston, Taipei, Sense Publishers.

Freire P. (2007), Pedagogy of the oppressed. 30th Anniversary Edition. New York, London, Continuum.

Hodgson N., Vlieghe J. \& Zamojski P. (2018), Education and the Love for the World: articulating a post-critical educational philosophy. „Foro de Educación”, 16(24).

Korczak J. (1928), Wstęp. W: M. Rogowska-Falska, Zakład wychowawczy „Nasz Dom”: szkic informacyjny. Warszawa, Towarzystwo „Nasz Dom”.

Korczak J. (1978a), Pisma wybrane. T. 1. Warszawa, Nasza Księgarnia.

Korczak J. (1978b), Pisma wybrane. T. 3. Warszawa, Nasza Księgarnia.

Kowzan P. (2017), Dydaktyka zorientowana na wspótpracę równych. Typy relacji ze studentami podczas wspólnej pracy badawczej. „Hybris”, 36.

Kowzan P. (2018), Edukacja wobec groźby wojny. „Parezja”, 1(9).

Kubicka D. (2016), Doniosłość codzienności w filozofii wychowania Janusza Korczaka. „Nauki o Wychowaniu. Studia Interdyscyplinarne", 1(2).

Lewin A. (1986), Tryptyk pedagogiczny. Korczak - Makarenko - Freinet. Warszawa, Nasza Księgarnia.

Lewin A. (1999), Korczak znany i nieznany. Warszawa, Ezop Agencja Edytorska, WSP ZNP.

Lewis T. (2008), Defining the Political Ontology of the Classroom: Toward a Multitudinous Education. „Teaching Education”, 19(4).

Masschelein J., Simons M. (2008), The Governmentalization of Learning and the Assemblage of a Learning Apparatus. „Educational Theory”, 4(58).

Rancière J. (1991), The ignorant schoolmaster: Five Lessons in Intellectual Emancipation. Stanford, CA, Stanford University Press.

Rancière J. (2004), The philosopher and his poor. Duke, Duke University Press.

Smolińska-Theiss B. (2013), Spuścizna pedagogiczna Janusza Korczaka. Pytania o uniwersalność i aktualność idei. W: B. Smolińska-Theiss (red.), Rok Janusza Korczaka 2012. Nie ma dzieci sa ludzie. Warszawa, Biuro Rzecznika Praw Dziecka.

Starego K. (2016a), Odmowa teraźniejszości, czyli o odbywatelnianiu dzieci i udziecinnianiu obywateli. „Teraźniejszość - Człowiek - Edukacja”, 3(75).

Starego K. (2016b), Poza dyskurs kompetencji w edukacji krytycznej. ,,Trzeci termin” oraz Paula Freirego i Jacquesa Rancière'a idea dialogu zapośredniczonego. „Forum Oświatowe”, 1(55).

Starego K. (2017), Od pedagogiki kolektywu do pedagogiki kolektywizujacej. Idee pedagogiczne Antona Makarenki w świetle filozofii i pedagogiki wspólnotowości. „Problemy Wczesnej Edukacji”, 4(39). 
Szkudlarek T. (2017), Punk Theory: The future of thinking in the time of no future. „Research in Education", 97(1).

Szkudlarek T. (2018), Postulational Rhetoric and Presumtive Tautologies: The Genre of the Pedagogical, Negativity, and the Political. „Studies in Philosophy and Education”, 4(38).

Todd S. (2010), Pedagogy as Transformative Event: Becoming Singularity Present in Context. PESGB Conference, Oxford, March 26-28. https://s3.amazonaws.com/arena-attachments/74957/Todd.pdf, 16.07.2019.

Vlieghe J. (2016), Edukacja w warunkach szkolnych. Ku pedagogice skupionej na rzeczy. „Studia i Badania Naukowe. Pedagogika", 10(1). 